\title{
Biodiesel production from sunflower in Greece
}

\begin{abstract}
This paper regards research for evaluation of the effect of the surface and subsurface drip irrigation method in the production of biodiesel from sunflower crop and in the saving of irrigation water, and in economic performance which directly concerns the Greek producers. The research was conducted in the Central Greece, in a field in the Farm of the University of Thessaly. The following treatments were organized: a) the surface (AUTO (E)) and b) the subsurface $(\operatorname{AUTO}(\mathrm{Y}))$ drip irrigation method, in which the irrigation was scheduled by an automatic evaporation pan. The research concerns the growing seasons of the years 2011 and 2012
\end{abstract}

Keywords: sunflower, biodiesel, methods of irrigation, saving irrigation water
Volume 2 Issue 3 - 2017

\author{
Karatasiou E, Papanikolaou C, Makrantonaki \\ SM \\ Department of Civil Engineering, University of Thessaly, Greece
}

Correspondence: Karatasiou E, Department of civil

Engineering, Crop Production and Rural Environment, University of Thessaly, Fytokou, 384446,Volos, Greece, Tel 694369182I. Email kareilar@yahoo.gr

Received: November 16, 2016 | Published: March 24, 2017

\section{Introduction}

The climate change constitutes one of the most important environmental, social and financial invitations worldwide Parry et al. ${ }^{1}$ and because of her; the water constitutes today a critical natural resource, in limited availability. The agricultural sector because of the direct dependence of the weather conditions owned in the sectors that will be most affected by climate change, consumes about the $80 \%$ of available water resourses. Despite the fact that, the demand of irrigation water is high, the irrigation efficiency is low, while many researchers worldwide have studied the dependence of agricultural production on the frequency and quality of irrigation water Doorenbos \& Kassam. ${ }^{2}$ Worldwide, the current regime in the irrigation sector characterized from lack of detailed planning and irrational water consumption, because of: a) non exact definition of crop water needs with result the excessive irrigation Bohnert \& Bressan $^{3} \mathrm{~b}$ ) reducing the efficiency of irrigation water which ranging in $80-30 \%{ }^{4}$ and c) extension of irrigated land without corresponding of water resources and the intensify of production for increase performance and therefore, to increasing requirements in irrigation water. ${ }^{5}$ Under these, the contemporary irrigated agriculture must turn to the effective and sustainable use of water, with purpose its saving. Fact which it can be done with proper scheduling of irrigation and use of innovative practices in irrigation methods. In this paper applied the drip irrigation method, which is the most promising method for use combined with conditions in water shortage and for that reason applicable to a wide range of soils and crops. ${ }^{6-8}$ Furthermore, presents its ability application in many provisions with a range of benefits to water saving and combined with many automation. ${ }^{9-13}$ The rapidly increase of energy demand has become one of the major issues to the modern world and presently, most of the covered by fossil fuels. ${ }^{14}$ The fossil fuels burning lead to adverse environmental effects, such as the air's pollution increase and the greenhouse gases, while alongside reduced alarming their stock. The increasing the use of Renewable Energy Sources constitutes the apparent solution of problem. ${ }^{15,16}$ One of the most promising alternatives solutions to replace of conventional - fossil fuels are the energy crops, which included in Renewable Energy Sources and from which produced biomass and liquid Biofuels. As "biomass" is called any material, derived from living or recently deceased (plant or animal) organisms. ${ }^{17}$ Biomass shows significant advantages, such as the fact of the abundance in nature, the easy finding, the low content in $\mathrm{S}$ and the low production in ashes..$^{18}$ Furthermore, the liquid biofuel, biodiesel, which comes from a wide range energy crops, considered a promising fuel, as is available in almost all countries of the world. Even the use of this alternative fuel in agricultural production of the country, through the use of agricultural machinery already studied extensively in Austria ${ }^{19}$ and in other European countries.

Sunflower (Helianthus annuus L.) constitutes one of the major crops of edible oil production around the world, because of the high content of seeds in oil, which is about in $49-62 \% .^{20}$ Further, included in energy crops, since after industrial processing of sunflower oil it is possible to produce biodiesel. ${ }^{21}$ The recent years, sunflower crop has intensified in Spain, ${ }^{22}$ studied intensively in Switzerland and is already crop with economic importance in France and Italy. Sunflower considered relatively hardy plant in drought, because of deep root system. According to Schneiter, ${ }^{23}$ most of sunflower crop in U.S.A. developed under rain fed conditions and in areas with an annual average rainfall between $350-550 \mathrm{~mm}$, yields are satisfactory. The greater demands of the plant in water appear from the step of the unfolding of the inflorescenes till the anthesis. In Greece, most of the sunflower crop grows under rain fed conditions. But by irrigation application even if it is deficient, achieved quite satisfactory yields. ${ }^{24}$ For this, imposed the rational application irrigation water in crop, using modern methods and at the appropriate stage of development. Furthermore, for the Greek producers the sunflower can be a promising alternative crop, as can be exploited favored agricultural areas as to the sufficiency of water and because of the integration of "contract farming", which is guaranteed from the beginning the sale of the product. With this investigation sought the study of the effect of the automated surface and subsurface drip irrigation method in biodiesel production from sunflower crop and in the water saving, and in the economic performance.

\section{Materials and methods}

The experimental procedure was held at the Farm of University of Thessaly to Velestino of Magnesia (Central Greece), during the growing seasons of the years 2011 and 2012. The experimental plan that used, was a completely randomized design and included two treatments, in four replications (Figure 1). The treatments were: a) the surface $(\mathrm{AUTO}(\mathrm{E}))$ and $\mathrm{B})$ the subsurface $(\mathrm{AUTO}(\mathrm{Y}))$ drip irrigation, where the irrigation was scheduled by an automatic evaporation pan. The cultivation tasks were used were the same for all treatments and in accordance with the general cultivation practice in the region. The irrigation dose which was applied was equal to $100 \%$ of the crop water 
needs for both treatments. Upon analysis, the mechanical composition of the soil of the experimental plot was $48 \%$ sand, $23 \%$ clay and $29 \%$ silt, while the soil $\mathrm{pH}$ was 7,8 and the organic substance was $0,97 \% .{ }^{25}$ The crop grown in the content low input, so during the two growing periods no kind of fertilization was carried out.

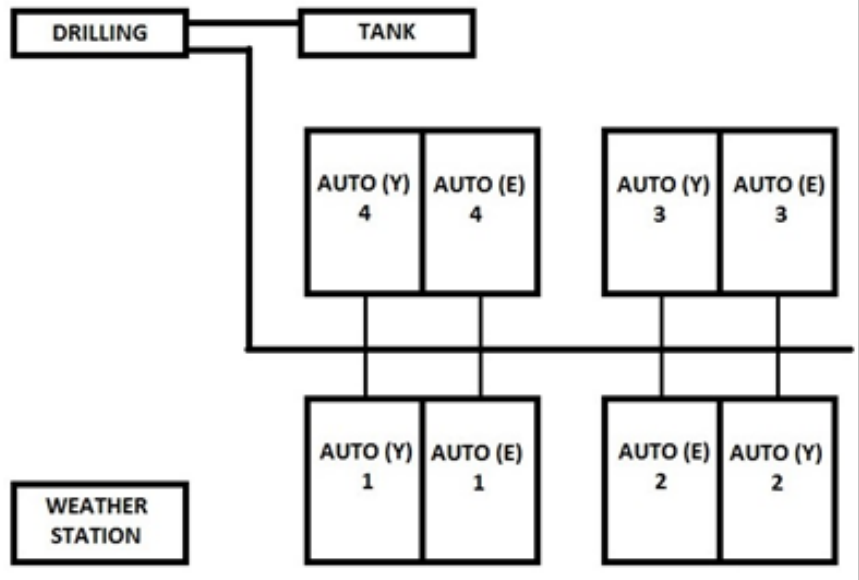

Figure I Layout of the treatments and replications in the experimental field.

The area of each experimental unit (plot) occupying a total area $56 \mathrm{~m}^{2}$ and included six seeding lines. The distance of the plants on the line was about $12 \mathrm{~cm}$ and the distance between rows was $80 \mathrm{~cm}$. The drip lines were constructed from $20 \mathrm{~mm}$ diameter polyethylene and spaced apart $1,60 \mathrm{~m}$. In the same manner they were at $45 \mathrm{~cm}$ a depth below of the ground surface. Positioning of the drip lines of subsurface system performed by a special instrument. The distance of drippers was $80 \mathrm{~cm}$ and were self-cleaning and self- regulating, with each flow rate $2,31 \mathrm{t} / \mathrm{h}$. in the first ten days of April for both periods, was performed the sowing (quantity $0,89 \mathrm{~kg} / 0,1 \mathrm{ha}$ ) using a crop seeder for linear cultivations (with four units). A Pioneer brand sunflower hybrid was used, which is called PR64A63. Pre-emergent and post- emergent herbicides were used with the application of the herbicide STOMP (quantity $350 \mathrm{cc} / 0,1 \mathrm{ha}$ ), during the two growing periods. In order to avoid interactions from neighboring seed lines and experimental plots, during both growing periods, weekly measurements of crop growth characteristics were carried out from the middle sowing lines of each plot. Furthermore, indications of sunflower oil was revealed and therefore the energy (biodiesel), which is the main objective of this investigation, after the appropriate laboratory analysis of the final seed production.

The scheduling irrigation was held by the automatic evaporation pan, in which there was a water-level measuring probe (WL1). Its operation was based in the method of evaporation pan type A. by using this system is not required the physical presence of the operator to obtain the indication of evaporation, for the beginning and the end

\section{3lt sunflower oil (Figure 2).}

Table I Total quantity of irrigation water $\left(\mathrm{m}^{3} / \mathrm{O}, \mathrm{Iha}\right)$ applied per treatment and growing period, final seed production $(\mathrm{kg} / \mathrm{O}, \mathrm{Iha})$ and irrigation water use efficiency $\left(\mathrm{kg} / \mathrm{mm} \mathrm{H}_{2} \mathrm{O}\right)$ of irrigation. The sensor, was positioned in the perforated pipe within the basin of evaporation pan, recorded the change in the value of the electric potentional. This value was transferred to the data logger and translated by the equation in $\mathrm{mm}$ of water which existed in the pan. A command was set, in the data logger, to sum the difference of daily evaporation rates and then command in Relay to start the irrigation when the sum mentioned before reached the $30 \mathrm{~mm}$. The limit of $30 \mathrm{~mm}$ of irrigation dose was set so as to be less than or at most equal to the practical irrigation dose, as estimated by hydrodynamic parameters of the experimental field soil (the water retention, the permanent wilting point, the specific gravity ground effect), the depth of the root zone of the crop, the daily reference evapotranspiration etc. When a specific number of hours were completed, which was related to the hourly flow of water drippers, their distance on and between the irrigation lines, was set to be done the interruption of the irrigation. Data processing which was collected was carried out by the use of the statistical package SPSS Version 18. The statistical processing was held by the method of Analysis of Variance (ANOVA) at the 5\% significance level. While, the classification of averages was done by the application of Duncan's multiple-range test. ${ }^{24}$

\section{Results and discussion}

In Table 1 is presented the amount of water that was applied for crop irrigation, for which during the growing periods, no difference occurred between the treatments at the 5\% significance level. Also, between the growing periods was not presented statistically significant difference in the applied amount of water. The final seed production $(\mathrm{kg} / \mathrm{ha})$, which is the final product which is marketed by the producer and it is important for this research, is presents in the same table. There was no difference at the 5\% significance level for treatments between the growing periods, while statistically significant difference between treatments was presented during the growing period of 2011, probably due to the randomness of the sample. A slight tendency of superiority observed as for the final product was obtained for both growing periods in the treatment which was implemented subsurface drip irrigation. Finally, in the same table shows and the irrigation water use efficiency (W.U.E.). As the efficiency of irrigation water use is defined the ratio of the total production to the total irrigation water. ${ }^{26}$ In the W.U.E. not presented difference at the 5\% significance level for the treatments between the same growing period and between the two growing periods. A slight trend superiority was presented about the W.U.E. in the treatment where was applied the subsurface drip irrigation. Table 2 shows for both periods, the produced biofuel energy (MJ/ha), for which there not occurred a difference at the 5\% significance level between the two growing periods. Statistically significant difference occurred only between treatments during the growing period of 2011, because of the difference was compared to the corresponding quantity of seed. The quantity of energy sunflower exported taking into account that, each liter of oil corresponds to 1 ,

\begin{tabular}{|c|c|c|c|c|c|c|}
\hline \multicolumn{3}{|c|}{ Irrigation water quantity $\left(\mathrm{m}^{3} / 0, \mathrm{Iha}\right)$} & \multirow{2}{*}{$\begin{array}{l}\text { Final production seed }(\mathrm{kg} / 0, \mathrm{Iha}) \\
20 \mathrm{II}\end{array}$} & \multicolumn{3}{|c|}{ W.U.E. $\left(\mathrm{kg} / \mathrm{mm} \mathrm{H}_{2} \mathrm{O}\right)$} \\
\hline Treatment & 2011 & 2012 & & 2012 & 2011 & 2012 \\
\hline Auto(E) & $508^{\mathrm{a}}$ & $517^{\mathrm{a}}$ & $348,4^{b}$ & $361,6^{\mathrm{a}}$ & $0,69^{\mathrm{a}}$ & $0,69^{a}$ \\
\hline Auto(Y) & $506^{\mathrm{a}}$ & $519^{a}$ & $391,2^{\mathrm{a}}$ & $374,8^{\mathrm{a}}$ & $0,77^{\mathrm{a}}$ & $0,72^{\mathrm{a}}$ \\
\hline
\end{tabular}


Table 2 Energy production from sunflower oil ( $\mathrm{MJ} / 0$, Iha) per treatment for the years 2011 and 2012

\begin{tabular}{llc}
\hline \multirow{2}{*}{ Treatment } & \multicolumn{2}{c}{ Energy production (MJ/0, I ha) } \\
\cline { 2 - 3 } & 2011 & $\mathbf{2 0 I 2}$ \\
\hline Auto (E) & $5402,8^{\mathrm{b}}$ & $5676^{\mathrm{a}}$ \\
Auto $(\mathrm{Y})$ & $6127,4^{\mathrm{a}}$ & $5547,6^{\mathrm{a}}$
\end{tabular}

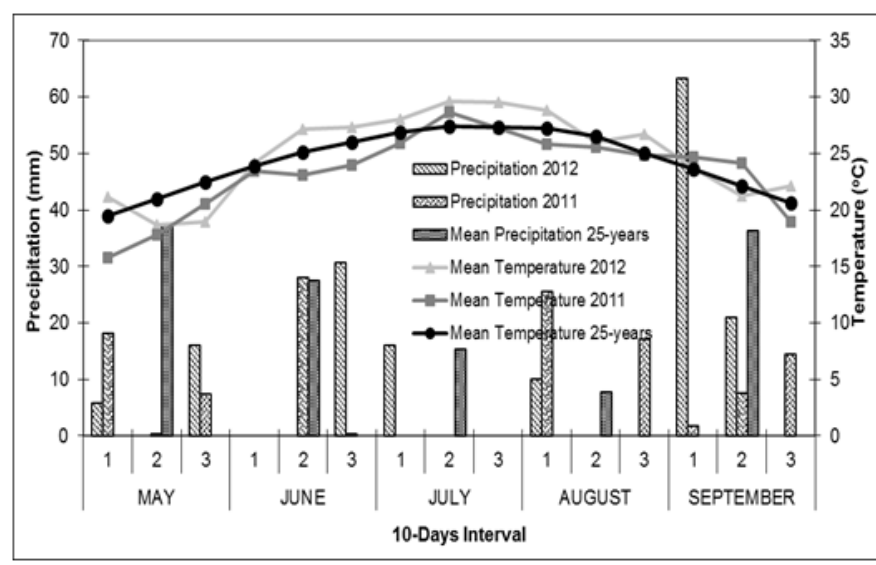

Figure 2 Climate data of the growing periods $201 \mathrm{I}$ and 2012 compared to the last 25 years.

\section{Conclusion}

In this research was studied the automated method of drip irrigation, which was based in the use of automatic evaporation pan, which showed good results as to the quantity of water consumed as well as to the seed production. Its use brought many advantages, such as reducing travel to and from the field, optimization of water use and avoidance of the waste of energy. From the above it is clear that for Greece, in the near future, sunflower could be an alternative crop due to the multiple advantages it offers. Specifically, the producer has the possibility of economic exploitation of the whole plant, because of oil seeds produced both edible oil, and the liquid biofuel, the biodiesel, and from the crop residues (leaves and stems), solid biofuel. Furthermore, included in the crop system "contract farming", thus originally guaranteed sale of the finished product of the producer, i.e. seed and even at a much higher price $(0,37 / \mathrm{kg}$ to 2011 and $0,42 / \mathrm{kg}$ to 2012) from other cultures of Central Greece such as wheat, barley, corn, etc. Therefore, is suggested to Greek producers, the cultivation of sunflower for the biodiesel production, using the automated evaporation pan for scheduling irrigation in combination with the method of subsurface drip irrigation, because during the two growing periods showed higher seed production and water use efficiency.

\section{Acknowledgements}

None.

\section{Conflict of interest}

The author declares no conflict of interest.

\section{References}

1. Parry ML, Arnell NW, McMichael AJ, et al. Millions at risk: defining critical climate change threats \& targets. Global Environmental Change. 2001;11(3):181-183.
2. Doorenbos J, Kassam AH. Yield Response to Water. FAO Irrigation and Drainage. 1979;33:193.

3. Bohnert HJ, Bressan RA. Abiotic stresses, plant reactions, and new approaches towards understanding stress tolerance. In: Noesberger J, Geiger HH, editors. In: Crop Science: Progress and Prospects. USA; 2000. p. 81-100.

4. Litskas VD, Aschonitis VG, Lekakis EH, et al. Effects of land use and irrigation practices on $\mathrm{Ca}, \mathrm{Mg}, \mathrm{K}, \mathrm{Na}$ loads in rice - based agricultural systems. Agricultural Water Management. 2014;132(2):30-36.

5. Caviglia OP, Sadrasc VO, Andradeb FH. Intensification of agriculture in the south-eastern Pampas I. Capture and efficiency in the use of water and radiation in double- cropped wheat- soybean. Field Crops Research. 2004;87(2-3):117-129.

6. Sakellariou-Makrantonaki M, Papalexis D, Nakos N, et al. Effect of modern irrigation methods on growth and energy production of sweet sorghum (var. Keller) on a dry year in Central Greece. Agricultural Water Management. 2007;90:18-189.

7. Badr MA, Taalab AS. Effect of drip irrigation and discharge rate on water and solute dynamics in sandy soil and tomato yield. Austr J Bos Appl Sci. 2007;1(4):545-552.

8. Kalfountzos D, Alexiou I, Kotsopoulos S, et al. Effect of subsurface drip irrigation on cotton plantations. Water Resour Manage. 2007;21(8):13411351.

9. Sakellariou-Makrantonaki M, Kalfountzos D, Vyrlas P. Water saving and yield increase of sugar beet with subsurface drip irrigation. Global Nest: The International Journal. 2002;4(2-3):85-91.

10. Sakellariou-Makrantonaki M, Soulti A, Papadakis E, et al. Subsurface drip irrigation of sorghum with treated municipal wastewater. Proceedings of EWRA Symposium on Water Resources Management: New Approaches and Technologies. Greece; 2007. p. 353-360.

11. Sakellariou-Makrantonaki M, Papanikolaou C, Tzimopoulos C. Application of smart irrigation systems in energy plants. Proceeding of $11^{\text {th }}$ conference of Greek Hydrotechnical Association and $7^{\text {th }}$ conference of Greek Scientific Water Management Committee. Greece; 2009.

12. Sakellariou-Makrantonaki M, Giouvanis V, Soulti A, et al. Watersaving by irrigating two varieties of Sorghum (Energy Plant) with treated municipal wastewater: A 3-years study in Central Greece. Fresenius Environmental Bulletin. 2012;21(1A):207-205.

13. Ramkumar S, Kirubakaran V. Biodiesel from vegetable oil as alternate fuel for C.I. engine and feasibility study of thermal cracking: A critical review. Energy Conversion and Management. 2016;118:155-169.

14. Lemus R, Lal R. Bioenergy crops and carbon sequestration. Critical Reveiw Plant Science. 2005;24:1-21.

15. Sakellariou-Makrantonaki M, Nakas C, Dimakas D. Applying biosolids in combination with deficit irrigation on crop of energy plant. Proceedings of $8^{\text {th }}$ National Agricultural Engineering Conference Volos. 2013. p. 92-96.

16. Biomass energy resources. Forest Research.

17. Bilgic E, Yaman S, Haykiri-Acma H, et al. Limits of variations on the structure and the fuel characteristics of sunflower seed shell through to $\mathrm{r}$ ref action. Fuel Processing Technology Journal. 2016;144:197-202.

18. Mittelbach M, Worgetter M, Pernkopf J, et al. Diesel fuel derived from vegetable oils: preparation and use of rape oil methyl ester. Energy in Agriculture. 1983;2:369-384.

19. Zurrer H, Bachofen R. Yields of Three Cultivars of Sunflowers in Switzerland. Biomass. 1985;7:297-302.

20. Friedt W. Present state and future prospects of biotechnology in sunflower breeding. Field Crops Research. 1992;30:425- 442. 
21. Bonilla JL, Chica A, Ferrer JL, et al. Sunflower stalks as a possible fuel source. Fuel. 1990;69:792-794.

22. Schneiter AA. Production of semi dwarf and dwarf sunflower in the northen Great Plains of the United States. Field Crops Research. 1992;30:391-401.

23. Steduto P, Hsiao T, Fereres E, et al. Yield Response to Water, FAO Irrigation and Drainage, Paper No 66. Rome, Italy; 2012. p. 500.
24. Mitsios I, Toulios M, Haroulis A, et al. Land study and mapping of the farm of the University of Thessaly in the area of Velestino. Greece: Zymel Publications; 2000.

25. Montgomery DC, Runger GC. Applied Statistics and Probability for Engineers. USA: John Willey and Sons; 1999. p. 430-530.

26. Howell TA, Cuenca RH, Solomon KH. Crop yield response. In: Hoffman, editor. Management of Farm Irrigation Systems. ASAE; 1990. 312S p. 